\title{
Status and Culture of Arbuscular Mycorrhizal Fungi isolated from rhizosphere of Endemic and Endangered Species of Kalapi (Kalappia celebica Kosterm)
}

\author{
Asrianti, Arif ${ }^{(1)}$, Tuheteru, FD. ${ }^{(1)}$, Husna ${ }^{(1)}$ Kandari, AM. ${ }^{(1)}$, Mekuo, IS. ${ }^{(2)}$, \\ Masnun $^{(2)}$
}

\begin{abstract}
Southeast Sulawesi has many local and endemic plants which important to be develop. One of them is kalapi (Kalappia celebica Kosterm) that has high quality of timber. However, kalapi population in nature have reduce and become rare. Irregular flowering period and limited seed are the problem, beside over exploitation that also threaten the existing of this species. Improve the plant growth and plant survival in degraded forest or marginal environmental conditions should be done using introduce biological agents such as arbuscular mycorrhizal fungi (AMF). The use of soil microorganism like AMF has been done for the conservation programs of rare, endemic and endangered species. This study aimed to determine the AMF status and to assess the culture of AMF which isolated from kalapi soil rhizosphere. Soil and root was taken in field, observations of AMF colonization and spores density carried out in the laboratory of Forestry, production of inoculum carried out in screen house Faculty of Forestry and Environmental Science, soil analysis was conducted in soil chemical laboratory, Faculty of Agriculture, Halu Oleo University. Results of study showed that spore density and AMF colonization have decreased with increasing of fertilizers doses application. $10 \mathrm{~g}$ sago waste application/pot and $1 \mathrm{ml}$ hyponex red/ pot is the best treatments which resulted the higher spore density and AMF colonization. The three genera of arbuscular mychorrizal fungi were found, namely Glomus, Gigaspora and Acaulospora genera. Glomus was recorded as the dominant species. This study was an initial step to provide AMF inoculums as biofertilizer to enhance growth of kalapi in support kalapi conservation and other endangered plants in the Southeast Sulawesi. AMF inoculums with sago waste are beneficial combination and can be used as biology fertilizer for plants.
\end{abstract}

Key words: Arbuscular mycorrbiza fungi, sago waste, hyponex-red, Kalappia celebica Kosterm

\section{Introduction}

Kalapi (Kalappia celebica Kosterm), an economically valuable local tree species, are now being researched and developed. Kalapi has beautiful and high quality of wood and give more economical benefits. However, their population have significantly decreased and become rare ((IUCN, 1994; UNEP-ECMC, 2007; Permenhut P57/2008) which is indicated by its declining in natural forests. Kalapi population in nature have reduce and become rare. Irregular flowering period, limited seed and lower of seed germination are the problems, beside over exploitation (no replanting) and illegal logging that also threaten the existing of this species.

Lecturer on Faculty of Forestry and Environmental Science, Halu Oleo University, Kendari, Jl. HAE.

Mokodompit, Kampus Hijau Anduonohu, Kendari. Southeast Sulawesi, Indonesia

2 Student on Faculty of Forestry and Environmental Science, Halu Oleo University, Kendari, Southeast

Sulawesi, Indonesia. 
Kalapi is endemic to Sulawesi included into family of Fabaceae with spreading area around Malili, South Sulawesi and Kolaka, Southeast Sulawesi. Publication about kalapi is still limited, so that required the strategies of kalapi protection on natural habitat and outside habitat (in situ and ex situ conservation). Regulation of the Ministry of Forestry No. P.57 / Forestry / II / 2008 on the National Species Conservation Strategy 20082018 that research should be done in saving of endangered species through study of ecology aspects, silviculture, genetics and properties of wood. Thus, biophysical research habitat, the distribution and regeneration potential in the field and domesticated species (exploration, collection and propagation), and wood quality needs to be done. Habitat conditions such as soil characteristics and biological conditions as a basis for considering the appropriate silvicultural methods. Research about kalapi cultivation has been done by Asrianti (2013;2014). However, no investigations on the fungal root association of this valuable species have been conducted. Whereas, the use of soil microorganism like AMF to enhance the growth of plant should be done for supporting the conservation programs of rare, endemic and endangered species.

AMF are association of mutuality symbiotic between higher plants and types of fungi which benefit for each other (Smith and Read, 2008). Most of terrestrial plants $( \pm 80 \%)$ associated with a group of AMF that potential for biological resources which found in nature and in various ecosystems (Cornwell, et al. 2001; Zubec, et al. 2011; Suharno, et al. 2011; Covacevich and Barbara, 2011; Souza, et al. 2016 ). AMF plays key role in the establishment, growth and survival of plants. AMF colonization can improve plant growth through its ability to utilize the nutrients in the soil, especially elements of $\mathrm{P}, \mathrm{Ca}$, N, Cu, Mn, K and Mg. (Smith and Read, 2008; Heijden et al., 2006; Aldeman et al. 2006). AMF colonizes on plant roots and expands the field to help root uptake with presence of external hyphae, that grows and develops into roots (Mosse, 2001). Other benefit is improve soil structure and aggregation (Burrows, 2014; Nichols, 2008), contributes to resistance of plant from root pathogens and nematodes by producing antibiotics (Alexopoulus et al. 1996; Bertha et al. 2005), protection against drought (Auge, 2001; Porcel and Ruiz-Lozano, 2004), resistance of environmental stress such as polluted site (Arul and Nelson, 2016) or heavy metal (Shabani et al. 2015). Selection of appropriate fungi with suitable host plant for specific environmental and ecological condition is the main challenges. AMF can be applied varied environment such marginal land, mined land, dry land or wetland.

AMF can be propagated through pot culture using host plants, inoculated with starter inoculums of spores or infected root (Brundrett, 1994). Fungi will be colonized on substrate and plant roots. Media that contain spores, infected root and hyphae can be used as an biological fertilizer. Environmental conditions, host type and AMF species are factors that plays important roles in AMF production. The aim of our studies was to determine the AMF status and to assess the degree of colonization by AMF, isolated from kalapi soil rhizosphere. The physico-chemical characteristics of soil samples were estimated. 


\section{Research Method}

\section{Tools and materials}

The tools that was used centrifuges, analytical balance, spores sieve $(710 \mu \mathrm{m}$, $125 \mu \mathrm{m}, 45 \mu \mathrm{m})$, knives, spores pinchers, dissecting microscope, Optika SZM-4 stereo microscope, Optika-B92 binooculer microscope, slide and cover glass, petridishes, scissors, pipettes, vials bottles, digital cameras, beaker, spray bottle, thermometer, lightmeter, and hygrometer. Materials which were used kalapi rhizosphere soil, glucose $50 \%$ (w/v), aquades, hyponex-red fertilizer, pot culture, Pueraria javanica seed, Zea mays seed, $10 \% \mathrm{KOH}$ solution (w/v), 2\% $\mathrm{HCl}$ solution, Melzer and PVLG solution, 2\% glycerol (v/v), 2\% Lactic acid (v/v), trypan blue $0.05 \%(\mathrm{w} / \mathrm{v})$.

\section{Collecting of rhizosphere soils for establishment of AMF trap cultures}

Rhizosphere soils were collected as much as $500 \mathrm{~g}$ at four samples in $20 \mathrm{~cm}$ depth, then homogenized and air dried, weighed as much as $50 \mathrm{~g} /$ pot for trap cultures. Media was arranged following zeolit-soil-zeolit composition in pot, then sow seed. Maintain for three month then drain the plant to stimulate spores.

\section{AMF spores extraction and identification}

Three month after the establishment of trap cultures, AMF spores were extracted using wet sieving method by Brundrett et al. 1994: $50 \mathrm{~g}$ soil inoculums dissolved into 200-300 $\mathrm{ml}$ of water, then stirred until homogeneous. Sieving in arranged sieve set with a size of $710 \mu \mathrm{m}, 125 \mu \mathrm{m}$ and $45 \mu \mathrm{m}$ respectively. Sieve the top sprayed with running water for easy filter material escaped, then released and the second filter back sprayed with running water. Distillate in a test tube and then added glucose to $60 \%$ using a pipette, then centrifuged at $2500 \mathrm{rpm}$ for 3 minutes. Supernatant solution was poured into $45 \mu \mathrm{m}$, washed with running water to remove glucose. The number of spores counted under a dissecting microscope. For observation of the spores under a microscope, the calculation is done based on the number and types of differences in morphology of spores. Identification of the morphological features include shapes, colors and the presence or absence of accessories, which is characterized by images of spore. Morphological properties of spores were determined in material mounted in polyvinyl alcohol lactic acid glycerol (PVLG) and in a mixture of PVLG/ Melzer's reagent on a slide. Identification of AMF spores was performed using Optika-B92 binookuler microscope and Optika SZM-4 stereo microscope.

\section{Root staining and the assessment of fungal colonization}

Pueraria javanica and Zea mays plant roots was prepared according to the modified root staining technique by Brundrett et al., 1994. Roots were washed with clean water, soaked in $2,5 \% \mathrm{KOH}$ for 24 hours and then rinsed in tap water. Root samples were then acidified in $2 \% \mathrm{HCl}$ for 24 hours and finally stained with $0.05 \%$ trypan blue in 2 lactic acid : 2 glycerol : 1 aquadest for 24 hours until analyzed. Root fragments $1 \mathrm{~cm}$ long were put on slides and squashed using cover slides. AMF colonization was identified on the basis of the presence of hyphae, vesicles, arbuscules, and auxilaria. To calculate the percentage of mychorrizal colonization. the formula was used:

The percentage of root infection $=$

The amount of infected roots

$\mathrm{X} 100 \%$

The amount of all observed roots 


\section{Results And Discussion}

\section{Trapping of AMF using soil inoculums from kalapi rhizosphere}

The physico-chemical characteristics of kalapi rhizosphere soils are presented in table 1.

Table 1. Physicochemical properties of soil for endemic and endangered plant Kalappia celebica Kosterm on Tanggetada subdistrict (community forest)

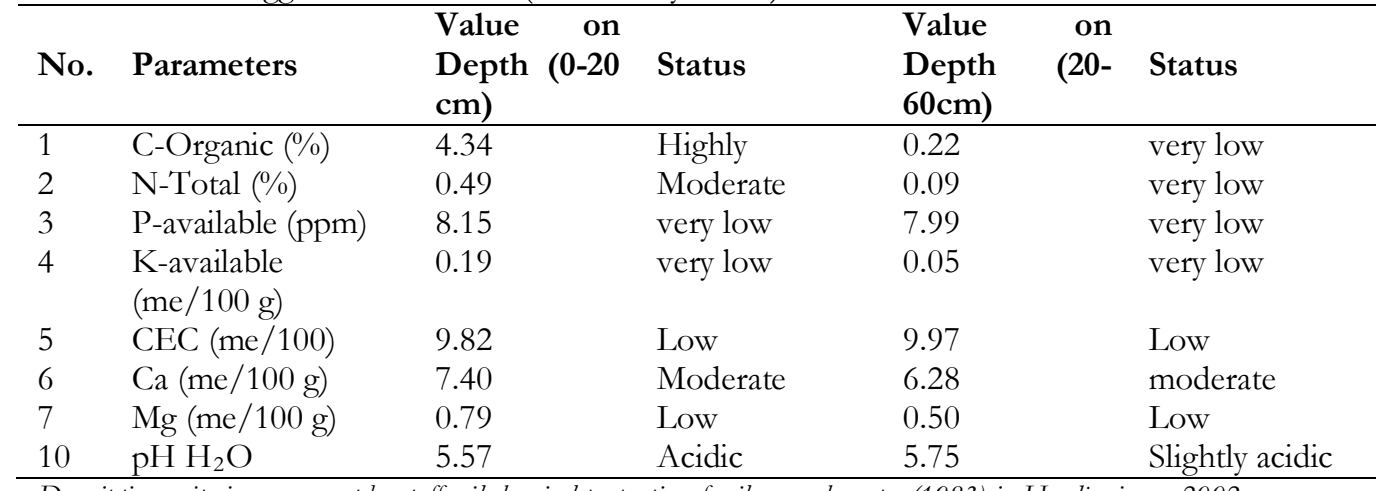

Description: criteria assessment by staff soil chemical properties of soil research center (1983) in Hardjowigeno, 2002

The analysis of soil showed that macro nutrient is very low and soil $\mathrm{pH}$ is categorized as acidic and slightly acidic. Kalapi required AMF, where AMF give benefit such as to improve soil fertility and to promote plant growth, particularly for infertile soils (Heijden et al., 2006). More research publication showed that the availability of high soil phosphorus strongly have negative affected for AMF development (Beenhouwer et al. 2015). In culture of AMF, growth of host plant should be improved because to provide root exudates for development of AMF colonized root. To determine the status of AMF and the degree of root colonization, it was conducted trap culture using two kinds of fertilizer such as hyponex-red and sago waste.

Research on observation of the effect of host plants and hyponex-red fertilizer application presented on picture 1 .
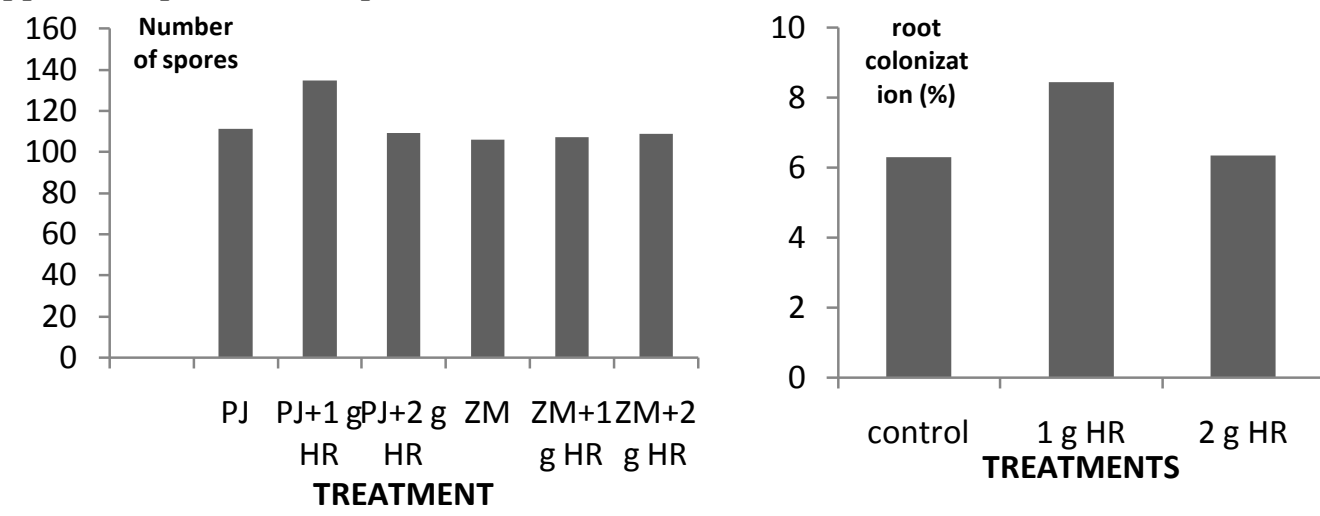

A

$\mathrm{B}$

Picture 1. Histogram showed the number of spores (a) and root colonization (b), PJ (Pueraria javanica), ZM (Zea mays), HR (Hyponex-red) 
In histogram (A) the effect of $1 \mathrm{~g}$ of hyponex-red application combined with host PJ gave the best results on number of spores. It also seemed that $1 \mathrm{~g}$ HR was able to improve root colonization. The properly of nutrient and compatibility with host would give the enhance of AMF development (Sylva et al. 2015). Hyponex is a foliar fertilizers, in which the content of $\mathrm{N}$ in red hyponex $25 \%$. Nitrogen helps in the formation of leaves which allow the metabolic activity of the plant such as photosynthesis can run well, thus photosyntate supply (source of nutrients) for plant growth can be provided (Husna, 2010). So there are many root exudates which than activities transcription of fungi, stimulate germination of spores and hyphae growth and colonization AMF (Pearson et al., 2009). In addition, P fertilization with dose and high solubility are reported to change abundance, colonizing and effectiveness of AMF propagules (Bhadulung et al., 2005). AMF tend to associate on low nutrient content especially the content of P (Smith and read, 2008). Tuheteru (2003) states that the AMF sporulation depends on the availability of phosphate, were the higher content of phosphorus $(\mathrm{P})$, caused the decrease of sporulation. Generally, the increase of nutrient doses will decrease AMF colonization and spores number.

It had been found three genera AMF on soil inoculum sources with different host and the addition of hyponex as inorganic fertilizers. Glomus is dominant genera which were found, with the characteristic of Glomus that has shaped spores globoid and have an attachment hyphae (INVAM, 2013). Glomus, generally, has round and oval-shaped with a brown-black color. Other is Gigaspora (1 species), and Acaulospora (1 species). Gigaspores has round shape and yellowish white color. Acaulospore has round shape, color is brownish yellow, but when it put in melzer, the color turns red and consisted of 2 layers with in outer layer have colorless or transparent. Glomus is dominant genera which showed the ability of spore to grow in widely range of environment. Optimum $\mathrm{pH}$ for Glomus sp. is 5.5 to 8 and Gigaspora sp. ranged from 4-6 (Tuheteru, 2003). Moreover, Glomus genera have potential to be developed as a biological fertilizer.

Other research, the effect of sago waste on production of AMF showed that the using of sago waste have a significant effect on colonization, spores number, and some plant growth variables.

- Spore number $\quad$ AMF Colonization

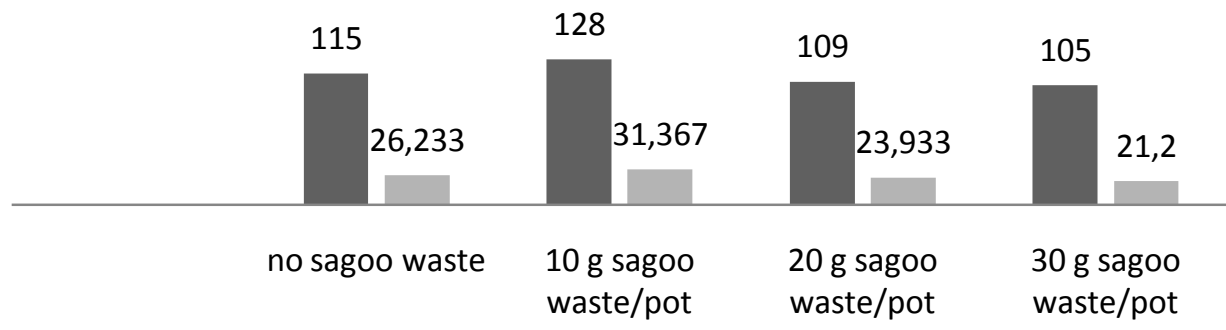

Treatments of sagoo waste (g)

Picture 2. Histogram of the effect of sago waste application on spore number and AMF colonization 
The increase of sago waste doses tend to decrease of spore number and AMF colonization. These results in accordance with Begoude et al. 2016 that AMF spore density was higher on low of fertilization doses.

In other case, AMF colonization is not related to the number of spores that it is produced, because the process is influenced by many factors such as the condition of inoculums, environment, host plant type and media (Siqueira et al. 1989). Vaast \& Zasoski (1991) reported that the long incubation time, the maturity level of spores affect the colonization. External factors such as humidity, environmental stress, and media can affect the spore germination and colonization AMF. Compatible host is also capable to support the growth and development of AMF. Furthermore, internal factors include infectivity and density of propagules.

\section{Treatments of sagoo waste $(g) \quad$ shoots dry weight $\quad$ root dry weight 1,203}

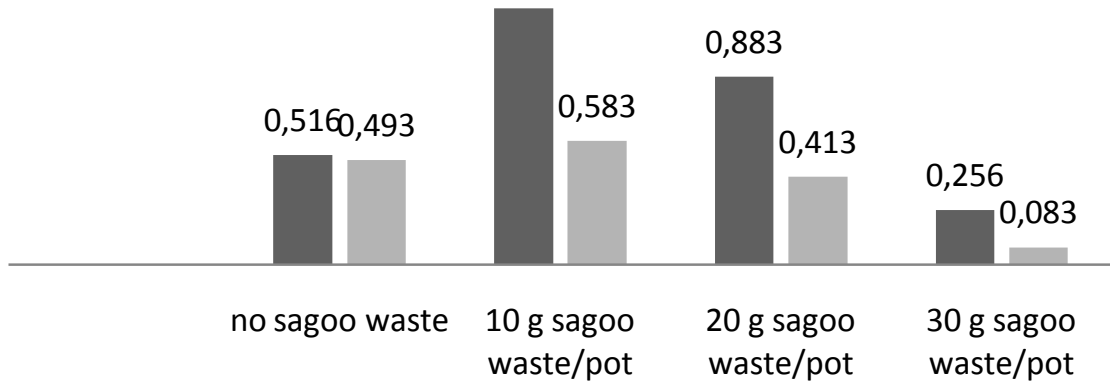

Picture 3. Histogram of the effect of sago waste application on shoot dry weight and root dry weight

Picture 3 also revealed that the increase of sago doses resulted on decreasing of shoots and root dry weight. According to Husna (2010) that sago waste can provide plants nutrients and consequently it can improve the growth of plant and maintain the photosynthesis process. Moreover, this process will supply all of the organic compound and energy for growth of shoots and roots and improve plant dry weight. In other word, metabolic activity can run well, thus the supply of photosyntate can promote the plant growth.
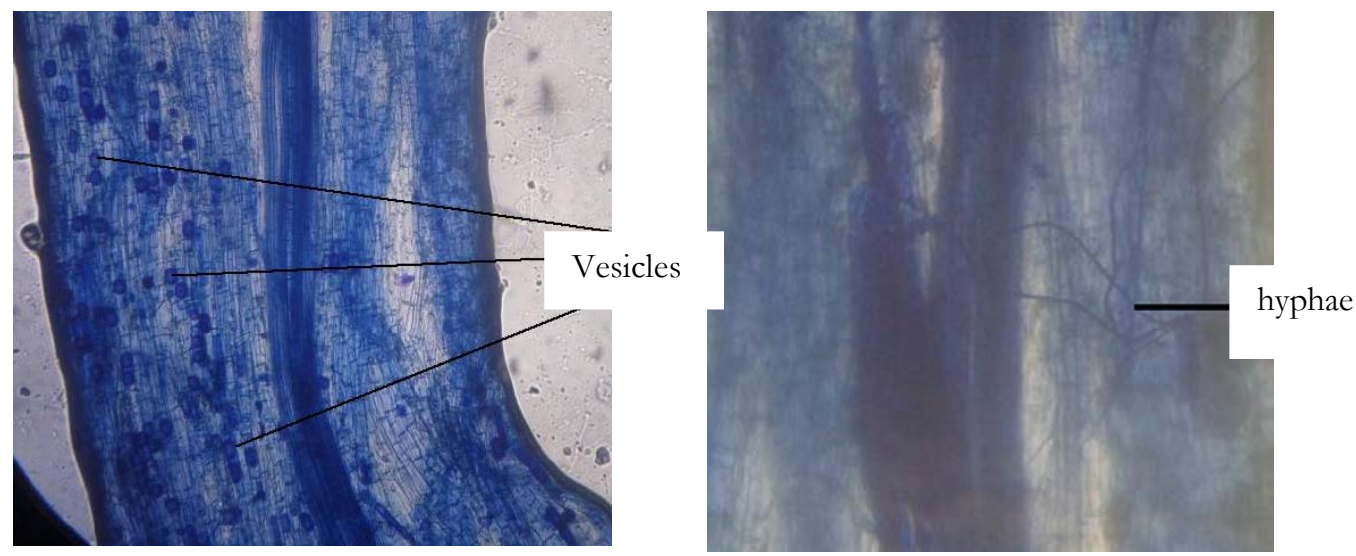

Figure 4. Fungal root colonization on root (vesicles and hyphae structure) in stain solution 
The present studies have found identified spores in genera Glomus, Gigaspora and Acaulospora. Glomus was a predominant genus in term of spores' density. A similar finding was obtained from rhizosphere soil under kayu kuku (Pericopsis mooniana) (Husna, 2010).

\section{Conclusion}

In conclude that the applications of fertilizer in properly doses can maintaining the production of AMF. Both hyponex-red (inorganic fertilizer) and sago waste (organic fertilizer) should be provided using appropriate and sufficient doses to improve the growth of host plant and production of AMF spores. AMF and sago waste inoculums have more benefit, in general, can increase the production of arbuscular mycorrhizal fungi in culture of AMF, and in long term use, AMF and residue of sago waste can be used for plant nutrient as bio-organic fertilizer which potential to be developed in supporting the growth and success of planting in the field.

\section{Acknowledgments}

This work was supported by the Ministry of Technology Research and The higher Education of Indonesia.

\section{References}

Arul, A., Nelson, R. 2016. Diversity of Arbuscular Mychorrizal Fungi in the Cement dust polluted site of Ariyalur Districts Tamil Nadu, International Journal of Advanced Research in Biological Science 3(1):215219.

Alexopoulos, CJ., Mims, CW., Blackwell, M. 1996. Introductory mycology, Fourth Edition, United States of America John Wiley \& Sons Inc.

Asrianti A. 2013. Konservasi Jenis Terancam Punah Kalapi (Kalappia celebica Kosterm) di Kecamatan Tanggetada Kabupaten Kolaka. Laporan Hibah Bersaing. Tahun I. Kendari.

2014. Konservasi Jenis Terancam Punah Kalapi (Kalappia celebica Kosterm) di Kecamatan Tanggetada Kabupaten Kolaka. Laporan Hibah Bersaing. Tahun II. Kendari.

Augẻ, RM. 2001. Water relation, drought and vesicular-arbuscular mycorrhizal symbiosis. Journal of Mycorrbiza $11: 3-42$

Begoude, DAB., Sarr, PS., Mpon, TLY., Owona, DA., Kapeua, MN., Araki, S. 2016. Composition of arbuscular mycorrhizal fungy associated with cassava (Manibot esculenta Crantz) cultivar as influenced by chemical fertilization and tillage in Cameroon. Journal of Applied Biosciences, 98:92709283.

Beenhouwer, MD., Geel, MV., Ceulemans, T., Muleta, D., Lievens, B., Honnay, O. 2015. Changing Soil Charactheristics Alter the Arbuscular Mychorrizal Fungi Communities of Arabica Coffee (Coffea arabica) in Ethiopia across a Management Intensity Gradient. Journal of Soil Biology and Biochemistry, 133-139. http://www.elsevier.com

Brundrett, M., Boucher, N., Dell, NB., Gove, T., Malajczuk, N. 1994. Working with Mycorrhizas in Forestry and Agiculture Kaiping Cina dalam: International Mycorrhizal Workshop

Burrows, RL. 2014. Glomalin production and infectivity of arbuscular mychorrizal fungi in response to grassland plant diversity. American journal of plant science, 103-111. http://www.scirp.org/journal/ajps.

Cornwell, WK., Bedford, BL., Chapin, CT. 2001. Occurrence pof Arbuscular Mycorrhizal Fungi in a Phosphorus-poor Wetland and Mycorrhizal response to Phosphorus Fertilization. American Journal of Botany, 88(10):1824-1829. 
Covacevich, F., Barbara, LL. 2011. Indigenous Arbuscular Mycorrhizae in Areas with Different Successional Stages at a Tropical Dry Forest Biome in Brazil. African Journal of Microbiology Research.

Heijden, MGA., Engel, RS., Riedl, R., Siegrist, S., Neudecker, A., Ineichen, K., Boller, T., Wiemken, A., Sande, IR. 2006. The Mycorrhizal Contribution to Plant Productivity, Plant Nutrition and Soil Structure in Experimental Grassland. International Journal of New Phytologist, 172:739-752.

Husna, 2010. Pertumbuhan Bibit Kayu Kuku (Pericopsis mooniana THW) Melalui Aplikasi Fungi Mikoriza Arbuskula (FMA) dan Ampas Sagu pada Media Tanah Bekas Tambang Nikel [Tesis]. Pascasarjana Unhalu. Kendari. (In Indonesian)

IUCN, 1994. IUCN Red List Categories. Prepared by the IUCN Species Survival Commission. IUCN, Gland Switzerland.

Houghton, R.A. 2005. Tropical Deforestation as a Source of Greenhouse Gas Emission. In Moutinho, P., Schwartzman, S. (Editor). Tropical Deforestation and Climate Change. Amazon Institute for Environmental Research. PP.13-22

Peraturan Menteri Kehutanan Nomor : P.57/Menhut-II/2008 Tentang Arahan Strategi Konservasi Spesies Nasional 2008-2018.

Marschner, 1992. Nutrient dynamics at the soil-root interface (Rhizosphere); In. Read DJ, Lewis DH, Fitter AH, Alexander IJ. 1992. Editor. Mycorrhizas in ecosystems. Singapore. CAB International.

Porcel, R., Ruiz-Lozano, JM. 2004. Arbuscular mycorrhizal influence on leaf water potential, solute accumulation, and oxidative stress in soybean plants subjected to drought stress, Journal of Experimental Botany 55(403):1743-1750

Schubler, A., Schwarzott, D., Walker, C. 2001. A new fungal phylum, the glomeromycota: phylogeny and evolution. Journal of Resources Mycol. 105 (12) 1413-1421.

Setiadi, Y. 2000. Mengenal mikoriza \& prospek pengembangannya sebagai pupuk biologis dalam bidang kehutanan Kendari. Makalah disampaikan dalam Seminar sehari hasil penelitian progam Pasca Sarjana Fakultas Pertanian UNHALU 22-23 September 2000.

Shabani, L., Sabzalian, MR., Pour, SM. 2015. Arbuscular mycorrhiza affects nickel translocation and expression of $\mathrm{ABC}$ transporter and metallothionein genes in Festuca arundinaceae. Journal of Mycorrbiza

Smith, SE., Read, DJ. 2008. Mycorrhizal symbiosis, Second edition Harcourt brace and company publisher San Diego London New York Boston Sidney Tokyo Toronto Academic press.

Sieverding, E. 1991. Vesicular-arbuscular mycorrhiza management in tropical agosystem Eschborne Deutsche Gesellschaft fur Technische Zusammenarbeit (GTZ) GmbH.

Sylva, FSB., Melo, AMY., Brandao, JAC., Maia, LC. 2015. Sporulation of Arbuscular Mychorrizal Fungi using Tris-HCl Buffer in Addition to Nutrient Solution, Brazilian Jounal of Microbiology 36:327-332.

Suharno, Kasiamdari, RS., Soetarto, ES., Sancayanisngsih, RP. 2016. Presence of Arbuscular Mycorrhiza Fungi on Fern from Tailing Deposition Area of Gold Mine in Timika, Indonesia. Journal of Environmental Bioremediation \& Biodegradation 4(1):1-7.

Tawaraya K, Y. Takaya, M. Turjaman, S.J. Tuah, S.H. Limin, Y. Tamai, J.Y. Cha, T. Wagatsuma and M. Osaki. 2003. Arbuscular Mycorrhizal Colonization of Tree Species Grown in Peat Swamp Forests of Central Kalimantan, Indonesia. Journal of Forest Ecology and Management 182: 381-386.

Tuheteru, 2003. Aplikasi asam humat terhadap sporulasi FMA dari bawah tegakan alami sengon (Paraserianthes falcataria (L.) Neilsen) asal Maluku.Skripsi. Institut Pertanian Bogor.

UNEP-WCMC. 2007. Strategies for The Sustainable Use and Management of Timber Tree Species Subject to International Trade: South East Asia. Cambridge, UK.

Zubek, S., Nobis, M., Blaszkowski, J., Mleczko, P., Nowak, A. 2011. Fungal Root Endophyte Association of Plants Endemic to the Pamir Alay Mountains of Central Asia. Journal of Symbiosis 54:139-149. 